\title{
The Research on the Problems and Countermeasures of Establishing Shandong Province's Red Cultural Economy Development-Taking Weifang as an Example
}

\author{
Zhang Yuelin ${ }^{1, a}$
}

\author{
${ }^{1}$ Shandong University of Finance and economics, accounting, Jinan, Shandong , China \\ Jinan City, Shandong Province 250000 \\ azyl18863657157@163.com
}

\begin{abstract}
The red culture is an advanced culture with Chinese characteristics that was created by the Chinese Communists, the advanced elements and the masses of the people during the revolutionary war. It contains rich revolutionary spirit as well as profound historical and cultural connotations. Thus, carrying out investigation on the inheritance of the red culture as well as the development status of the red cultural industry is significant for taking better actions to protect and carry forward the red culture in the Internet era, which can improve the revolutionary literacy of contemporary college students, and give full play to the function of the red culture in terms of party building, ideological, moral, and economic construction. Besides, it also offers constructive advice on how to integrate the economy and culture of Shandong Province in the new era. The survey of this paper adopts the questionnaire method, field survey method and document research method. Through the investigation of the status quo of red culture propaganda as well as the development status of red culture industry, the innovative brand strategy of "red culture+" is obtained, which puts forward innovative suggestions for the integrated development of Shandong's red culture and cultural industry. Compared with the existing advice for the development of cultural industry clusters, this paper puts forward a new strategy led by red culture as the core, which is highly innovative. In the meanwhile, this paper discusses the function of red culture in the economy and society from the two aspects of cultural impact on the economy and cultural and economic integration, which is of great importance, strong theory, and more comprehensive thinking dimensions and which is conducive to people who want to get a thorough understanding and positioning of the red culture. This paper has made a strategic layout, which provides reference for subsequent industrial research.
\end{abstract}

Keywords: culture impacts economy; integration development of culture and economic; "red culture +"; Internet cultural aggregation platform

\section{Chinese Library Classification No.: 790.6720 Document Identification Code: [B]}

\section{INTRODUCTION}

The year 2021 is destined to be an extraordinary year, in which special period of the centuries-old party, as a young student, the author walked into the party hall for learning about party history, perceiving the great red culture, absorbing the power of active as well as enterprising struggle, and at the same time, thinking in practice and thinking about how to further carry forward the red culture so that more people can accept, absorb and inherit the spiritual power of the red culture, thereby realizing the co-construction of the Chinese dream and finding a way to integrate the red culture with the local characteristic culture finally. Through creating a tourism business card of "Red Culture +", this paper aims to make Shandong Province realize the simultaneous improvement of economic and social benefits and put forward innovative advice for the development of the cultural industry in Shandong Province. 


\section{QUESTIONNAIRE SURVEY RESULTS}

A total of 302 questionnaires were issued in the survey, among which 302 were valid questionnaires. In the question about "whether culture influences the economy", $91.72 \%$ of the respondents agreed with this point of view, and offered a very powerful evidence for the premise of the argument of "the integration and mutual impact of culture and economy" in this paper; in the question about "Do you think that the contribution of publicity and understanding of the red culture to the local economy and society is reflected in many aspects", all options showed a high selection rate, proving the correctness of this paper's conclusion.

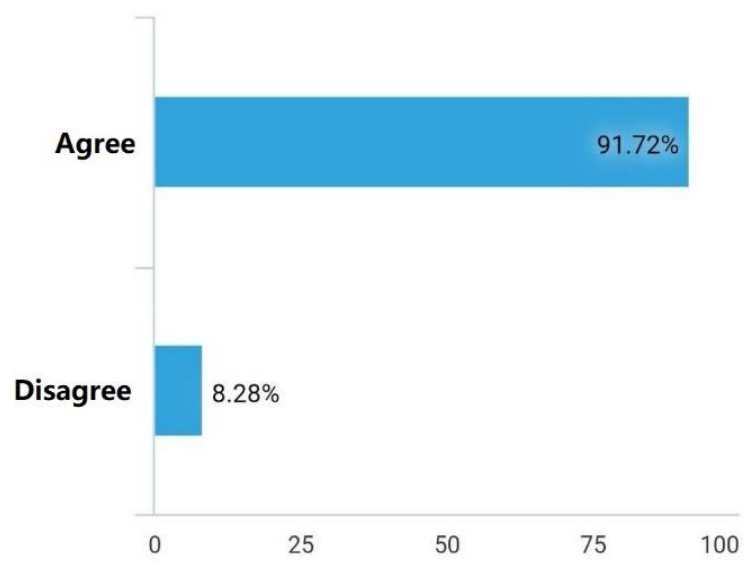

Figure 1 The results of the survey on "Whether culture influences the economy?"

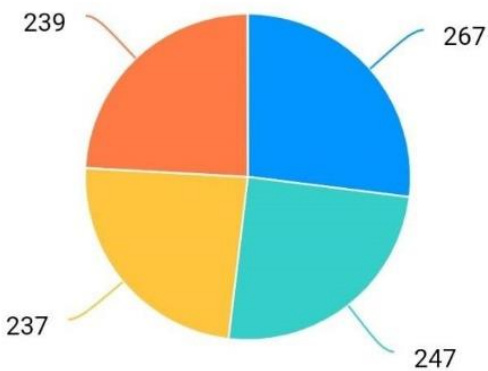

Develop cultural industries/red tourism and create distinctive brands.

Red culture unites public feeling, while cadres and the masses actively forge ahead. Promote the development of rural revitalization and poverty alleviation. Build a red education base to improve cultural quality.

$$
\begin{array}{l|l}
\text { Percentage } & \begin{array}{l}
\text { Subtotal } \\
\text { sorting }
\end{array}
\end{array}
$$

Figure 2 "Do you think that the contribution of publicity and understanding of the red culture to the local economy and society is reflected in many aspects?"

\section{THE DEVELOPMENT STATUS OF WEIFANG'S RED CULTURAL INDUSTRY}

\subsection{Developing advantages of the red cultural industry}

3.1.1. Richer red resources and their connotations that can be explored

Table 1. A list of some red resources in Weifang City

\begin{tabular}{|l|l|}
\hline Types & Representative carriers \\
\hline Weifang City Red & Wang Jinmei's former \\
residence
\end{tabular}

\subsubsection{Policy support}

The development of the red cultural industry is inseparable from the strong support of the government. In terms of the national perspective, the documents, such as Cultural Industry Revitalization Plan, Guiding Opinions on Financial Support for the Revitalization and Development and Prosperity of Cultural Industries (2010-2020), On the Implementation of the Protection and Utilization of Revolutionary Cultural Relics (20182022), etc. have been issued one after another. In terms 
of the perspective of Shandong Province, the government has successively issued Policies for Accelerating Cultural Development and Opinions on Promoting the Integration of Culture and Science and Technology. Besides, the Weifang Municipal Government has also issued Weifang City's Implementation Plan for Deepening Cultural System Reform and Weifang Cultural and Creative Industry Development Plan, which is committed to promoting the establishment of a cultural industry that is led by the red culture and making it become the pillar industry of Weifang's economy.

\subsubsection{Market expansion}

As the economic strength and the transformation of citizens' personal consumption concepts increase steadily, people have a higher pursuit of spiritual culture and have a clearer understanding of red buildings and red museums. At present, the cultural consumption market has initially taken shape, providing a good opportunity for the development of the cultural industry.

\subsection{Disadvantages of the development of the red cultural industry}

\subsubsection{Single investment subject of cultural industry and lack of talents}

The demand for funds mainly relies on the national fiscal expenditure, which not only increases the financial burden, but also restricts its development from many factors, reflecting strong uncertainty. The operation process can't bring high income, making the continuous development memorial be lacking in momentum. Secondly, there is a lack of compound talents who understand professionalism, management, and the market, making the operation and management mode of such memorial halls often not suitable for the demands of the development of modern market economy, which requires continuous innovation and improvement.

\subsubsection{Insufficient publicity and failure to play the leading part of the core}

Under the wrong guidance of the previous model of blindly pursuing the economy and growth rate, many officials and the masses still have the erroneous concept of emphasizing economics, who neglect culture. Some extravagant and corrupt officialdom styles are even more associated with working hard for the masses. The spirit and purpose of the Red Party are contrary to each other. The red tourism industry hasn't fully realized the purpose of educating people. If there is the need to reflect, the reason is also associated with the current failure to deeply explore the core values contained in the red resources. The scenic spots and education bases lack innovative design, and the deep cultural core hasn't been established, so people can't find out the spiritual sustenance of the red cultural brand. Only by fully exploring cultural connotations, combining local characteristics and orderly development on the basis of protecting red resources, can the propagandizing and popularizing of red culture have a further effect. As shown in Figure 3, which is the research on the publicity of red culture, the percentage increases from $1-5$. It can be seen that $50 \%$ of the people still didn't choose the highest option, while the publicity of red culture still requires to be improved. .

\subsubsection{Lack of integration with "Internet +" and failure to attract more young people}

The red culture failed to keep up with the trend of the new media era, which lacks the integration with the "Internet +", making the promotion of red culture failed to attract the attention of young people. It is necessary to take into account he integration with trend elements and look for integration points with other highlights, such as "Red + national style", "red + street dance", "red + food", etc., so that the red culture can be spread by means of diverse social circles, which will be the focus of the next step. In the meanwhile, it shall be noted that the dissemination of red culture through layers doesn't mean that red culture can be ridiculed or spoofed or abused. Any behavior which spoofs history and destroys the dignity as well as seriousness of history shall be severely resisted so as to create a good atmosphere for the spread of red culture.

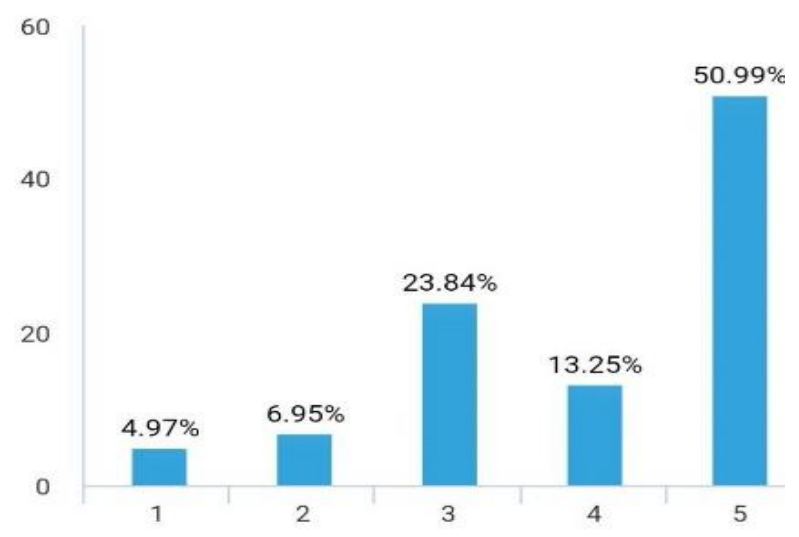

Figure 3 Survey results of "Red culture propaganda degree" 


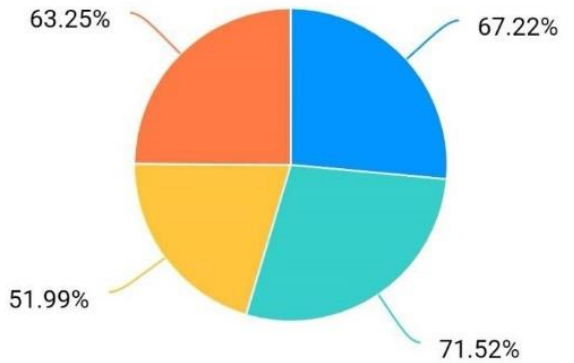

The way is not novel enough to attract people.

The cultural education industry lacks talent support, and red resources can't be fully explored. There is a lack of cultural atmosphere due to insufficient policies.

The resources are relatively scattered, and the aggregation is not achieved through the media.

Figure 4 Survey results on "What do you think the factors hindering the development of red culture propaganda is?"

\section{DEVELOPMENT STATUS WEIFANG'S CULTURAL INDUSTRY} OF

\subsection{Advantages of cultural industry development}

\subsubsection{Rich tour resources about folklore}

Weifang City is rich in cultural tourism resources. The traditional folklore tourism centered on the Yangjiabu wood plank New Year paintings and the Kite Festival has been fully developed. The "Thousand-Mile Folklore Tour" which integrates kite tours, ancient tours, tours of New Year paintings, and scenic spots has created China's largest distribution center as well as production center for kites and wood plank New Year paintings. The Shihu Garden, which is characterized by both north and south gardens, the authentic relics of Zheng Banqiao-one of the Eight Eccentrics of Yangzhou, and the former residence of the poet Li Qingzhao all make Weifang rich in cultural tourism resources, which lay the foundation for the development of the combination of both exploration and red culture.

\subsubsection{The rapid development of exhibition tourism}

Table 2. List of cultural exhibitions in Weifang City

\begin{tabular}{|l|l|}
\hline Region & Festivals \\
\hline Zhucheng & China Daysun Cultural Festival \\
\hline Urban area & $\begin{array}{l}\text { Weifang International Kite Festival, } \\
\text { Shandong-Taiwan Economic and } \\
\text { Trade Fair, Qingdao Weifang Week, } \\
\text { Hanting Radish Culture Festival }\end{array}$ \\
\hline Anqiu & $\begin{array}{l}\text { Qingyun Lake Ancestor Cultural } \\
\text { Festival, China Zhenshan Tourism } \\
\text { Festival }\end{array}$ \\
\hline Qingzhou & China Flower Expo \\
\hline Shouguang & China Vegetable Expo \\
\hline
\end{tabular}

\begin{tabular}{|l|l|}
\hline City & \\
\hline $\begin{array}{l}\text { Linqu } \\
\text { County }\end{array}$ & $\begin{array}{l}\text { Linqu Red Leaf Festival and Fantastic } \\
\text { Stones Festival }\end{array}$ \\
\hline $\begin{array}{l}\text { Changle } \\
\text { County }\end{array}$ & Changle International Gem Festival \\
\hline Gaomi City & China Red Sorghum Cultural Festival \\
\hline
\end{tabular}

The success of the Weifang International Kite Festival has led to the development of the "International Kite Festival", which also formed a complete kite chain. Weifang Arts and Crafts, represented by Weifang Kite, has an output value of 5.5 billion yuan since 2010 . The successful holding of the Weifang International Kite Festival is also for exhibition tourism. The development of MICE has played an exemplary and leading part. Currently, various exhibitions have blossomed, greatly promoting the development of exhibition culture and tourism.

\subsubsection{Problems on the development of cultural industries}

The development of the cultural industry in Weifang also faces many problems. The unsound tourism industry chain makes the lack of cooperation between industries, and the construction of high value-added tourism elements such as tourism shopping is not enough, which can't achieve comprehensive revenue.

Similar to the situation of red culture, the overall cultural industry is also facing insufficient innovation. The old theme of the theme can't attract audiences for its cultural core. The in-depth creation of cultural brands and promotion of characteristic cultural images have become the top priority, and the cultural connotation of "kites" must be explored so as to make the "Kite" cultural brand be deeply rooted in people's minds. It is not just a business card. Yangjiabu Wood Plank New Year Painting is a significant stop on the Weifang's Thousand-Mile Folklore Tour route, which focuses on people's pursuit of a beautiful as well as the simple life. It is included in the National Intangible Cultural Heritage Protection Unit List, but there are also some worrying matters. The lack of new ideas in the subject matter of New Year paintings is a key factor restricting the continued development of wood plank New Year paintings in the new era. Besides, the lack of professional talents, the declining impact of leading cultural industries, and the insufficient enthusiasm of young people for innovation in the cultural industry are also the factors which restrict the prosperity and stability of the cultural market.

Economy and culture support each other and promote each other. The Weifang International Kite Festival attracts capital for Weifang, promotes investment, and at the same time promotes employment. The injection of economic funds also offers the necessary conditions for the continuous operation of the kite club. In 1989, Weifang built the world's largest kite museum. The World Kite City Memorial Plaza completed in 2006 
currents functions as a good platform to promote the spread of kite culture. Thus, the development of cultural industries and red culture is extremely important.

\section{THE DEVELOPMENT IMPORTANCE OF WEIFANG'S RED CULTURAL TOURISM INDUSTRY}

\subsection{Interaction between culture and economy}

Economy determines culture, while culture reacts to economy. Red culture is a concentrated expression of the spirit of contemporary China. It is the reform and innovation of Chinese traditional culture by Chinese Communists armed with advanced Marxist theories. The national spirit of "constantly striving for becoming stronger and self-discipline and social commitment" is the concentrated expression of patriotism in the practice of social change. As far as the current situation of party member education is concerned, the structure of party members is complicated and the ideology is diversified. Some party members of political tendencies are marginalized, and the ideals as well as beliefs are relatively weak. Strengthening the education of red culture for party members and cadres is of great importance for advancing the party's governance capability and advanced nature, implementing the scientific outlook on development, and building the Chinese Dream. It is of great importance to responding to the country, call for deep integration into the "The Belt and Road Initiative" construction, give full play to the significant position of the Jiaodong Peninsula transportation hub, and have a far-reaching impact on the strategy of connecting the free trade zone and the strategy of strengthening the maritime city.

From the perspective of its own industrial positioning, from the perspective of global internationalization, the semiconductor luminescence industry in Weifang Hightech Zone is undergoing industrial chain integration, and regional industrial clusters promote the birth of the "China's Bright City" cluster culture, and are committed to becoming the "Bright City of China" and even the world. As one of the core cities in central Shandong, the development of Weifang can't be underestimated in the radiating and leading part of the surrounding areas, which is of great importance to the smooth implementation of the Shandong Peninsula City Cluster Development Strategy. It can be seen that the period from building a well-off society in all respects to basically realizing socialist modernization in the middle of the 21 st century is a significant period of strategic opportunity for Weifang. Only when we give full play to the party's key leadership role, implement the purpose of serving the people wholeheartedly, and maintain the party's absoluteness, purity and advancement, can we promote the sustainable development of the city and promote the smooth progress of the fight against poverty.

\subsection{The integration of culture and economy}

Culture is not only an economic force, but also an economic strength. The prosperity of the cultural industry is the best reflection of the close connection and mutual penetration of culture and economy in the world today. The former site of the Headquarters of the Anti-Japanese Armed Uprising in Niutou Town is a signature red tourist attraction in Niutou Town, Shouguang City, which also attributes to the development of local tourism in new economic growth points. Throughout the whole of Weifang City, the characteristic cultural industry is the kite festival and folk tourism. Combining the two will be helpful to the growth of the cultural industry. In the meanwhile, it will not forget the original intention and better inherit the red culture. In the relationship between the two, red Culture can not only cast the spiritual core of the city's cultural industry, but also assist kite culture to become a new cultural business card and highlight.

\section{ADVICE FOR PROMOTING THE DEVELOPMENT OF RED TOURISM IN WEIFANG CITY}

\subsection{Creation of "kite showing revolutionary times" business cards and series of travel brands}

China's kite culture is inseparable from precious traditional culture. It often reflects people's healthy and progressive spirit, as well as the pursuit of happiness, with rich meanings and varied patterns. Auspicious patterns can generally be divided into many types, such as "blessing" and "festival" "unity" and "striving". The excellent traditional Chinese culture is the source and foundation of the red culture. The traditional virtues of the Chinese nation are concentrated expressions and significant signs of the national spirit of unity, peaceloving, hardworking, courageous, and self-improvement with patriotism as the core. Red culture can be the connotation of kite culture that condenses excellent traditional culture. In the integration and development of the two, people can think of making diverse kite patterns represented by the theme of the red culture series, which not only describes and spreads red characters and advanced deeds, but also promotes Red culture promotes the national spirit. The themes of the series can include the spirit of the May Fourth Movement, the Red Boat Incident, the Jinggangshan Uprising, the Long March route, the heroes of the flood, etc. From the perspective of keeping up with the hot spots of the times and social progress, it can also make anti-epidemic theme kites, which can fully reflect the relay and inheritance of the younger generation in the journey of the new era. The wood plank New Year paintings can also use these themes to bring forth the new, and integrate the red spirit and the spirit of the times into traditional handicrafts, so that the Yangjiabu wood plank New Year paintings paintings carry forward its tradition again. In the meanwhile, in 
order to better build and promote the brand culture, making the "Kite Showing Revolutionary Times" series into commemorative coins is also a way.

In this process, it not only gives the cultural industry a red core to the region, but also makes the subsequent kite exhibition and kite museum in this region more attractive.

\subsection{The primary productive forces of Science and technology, as well as the innovative cultural communication methods}

Technology has a huge impact on the transformation of cultural communication methods. The application of VR and AR technology under the wave of new technology, the promotion of big data and cloud computing, the development of integrated media and new media promote the transformation of the propaganda method of the cultural industry, the red culture and the kite culture convergence can not only be carried out offline, but also be launched online. Besides, Internet media can also be used. On the one hand, a kite app has been developed, which integrated themes and a series of "Kite Showing Revolutionary Times" and "wood plank New Year paintings showing revolutionary times" have been launched, such as remembering the history-the 100th anniversary of the founding of the Communist Party of China "Kite Showing Revolutionary Times", Journey to the Future-Uniting and Fighting the Epidemic and Touching the Kite Showing Revolutionary Times, on-line production "Kite-knitting" and "Kite-flying", the live response of kite knowledge is small games such as wood plank New Year paintings color matching; on the other hand, it integrates scattered red resources, kite craftsmanship, wood plank New Year paintings old houses, etc., so that people can go online without leaving home. Have a clear understanding of these excellent cultural resources, such as launching the "Red" art festival on Yangjiabu Kite New Year paintings Online and making video creations, online cloud explanations and cloud tourism, etc. For instance, taking the changes of the family or family of the entire folk village of Yangjiabu as a background, and the changes in Kite New Year paintings are used as clues to produce TV dramas for broadcasting, thereby leading to better exploration and development of cultural resources in the protection and enhancing the cultural identity of the people of Weifang. In addition to the use of media, talents are the development of the cultural industry. The first support is that if you want to better retain intangible cultural artisans, it is a good option to launch a special platform to conduct live broadcasts of folk culture such as kites or wood plank New Year paintings, and transform traditional culture that lacks attention into popular culture in fun propaganda. It also attracts the participation of the younger generation in a more fashionable way, and injects fresh life and innovative talents into the cultural heritage and cultural industry.

\subsection{Government guidance and social participation}

Strengthen brand awareness and improve the "Kite Showing Revolutionary Times" cultural tourism industry chain. The development of the "six major elements" of Weifang's tourism industry is uneven, and there are weak links between the elements. Tourism companies have problems such as "small, scattered, weak, and poor", failing to form sufficient production capacity and social impact; while tourism The construction of high valueadded tourism elements such as shopping, tourism and entertainment consumption is not too strong, and the comprehensive income of the tourism industry can't be greatly increased. The government shall formulate overall development strategies and related policies, create a good environment for the development of cultural industries, do a good job in overall publicity, and promote the improvement of the industrial chain and coordinated development. Secondly, strengthen brand awareness and clarify its own positioning. On the one hand, focus on establishing urban cultural brands and create distinctive signs such as "Famous Kite City", "Kite City", "Kite Showing Revolutionary Times", and "Folk Culture City"; on the other hand, define its own positioning. Efforts will be made to implement the strategy of "the core of the city cluster in the central part of the Shandong Peninsula," the "transportation hub," and the "one belt and one road significant city", and carry out economic and cultural regional cooperation on this basis, and coordinate the development of the province's cultural industry, exhibition and tourism. "Line, point and surface" structure form the sustainable development of the overall cultural industry led by the red culture.

\subsection{Combining the "Kite Showing Revolutionary Times" industry with tourism}

Realize the benign interaction between the kite industry and the tourism industry. Under the leadership of the Kite Club, Weifang Kite has formed a complete industrial chain from material supply, production to market sales. After the implementation of the "Kite Showing Revolutionary Times" strategy, the kite showing revolutionary times in the industry is expected to achieve considerable industrialization. However, tourists during the kite festival rarely visit nearby attractions. Thus, for the kite club, the standardization, industrialization, and marketization of the kite club shall continue to be strengthened. For instance, it can be combined with the "Thousand-Mile Folklore Tour" route so as to create a "Kite Showing Revolutionary Times + folklore tour" tourist route; combine with the exhibition tourism of various places to create a "red culture + exhibition tour" tourist route. 


\subsection{Pay attention to the protection of carriers and "living bodies"}

Produce various forms of tourism products and cultivate innovative inheritors of kite culture. The wood plank New Year paintings and kite showing revolutionary times can not only be preserved in their original appearance, but also can be made into electronic and paper calendars, desk calendars, miniature ornaments, picture albums, and so on. As far as the status quo is concerned, the competition in the cultural industry driven by "Internet + " is basically a competition of talents, a competition of new compound talents who are both proficient in Internet technology and well versed in regional cultural characteristics. The local schools at all levels in Weifang shall set up relevant majors and courses in accordance with regional cultural characteristics to cultivate innovative talents for the development of the cultural industry in Weifang. In the meanwhile, the kite making process is lively and interesting. Such practical courses can be offered in elementary education schools such as kindergartens and elementary schools, starting from basic education, and fostering the feelings of love for hometown among primary school students. Professionals such as network engineering, animation, dance, tourism management and other majors in colleges and universities can also play their talents and make contributions in the in-depth exploration of platform development kite culture, the innovation of kite industry and the integration of kite resources.

\section{CONCLUSION AND SUGGESTIONS: COORDINATED DEVELOPMENT OF SHANDONG'S RED CULTURAL INDUSTRY - " RED CULTURE+" STRATEGY}

Similar to the Weifang area, through investigating and integrating the development status of red culture in many places, it is found that red culture can be combined with local distinctive regional cultures in many places, and promote the development of cultural industry in Shandong Province, forming a linkage effect, thereby expanding the red culture. The social impact and economic benefits of the cultural industry with culture as the core. Through the "Hometown of Yimeng, Holy Land of Confucius and Mencius, and Red Shandong", with the red culture as the innovative attraction and spiritual core, the creative cultural industry of "Red Culture +" will be created, and Shandong Province will be established on the basis of cultural tourism in various places. The overall cultural tourism brand, and the new promotional slogan is also an innovation and advancement of the "Hospitable Shandong People" slogan.
The cultural resources of Shandong Province are rich and colorful, but some resources have not yet been developed, and some are not fully developed. Thus, it is necessary to fully explore Shandong cultural resources and create a cultural tourism brand with regional advantages and characteristics. In the meanwhile, an online aggregation platform of "red culture + regional culture" is built through Internet technology to enhance the integrity of the cultural industry, which can also facilitate the public to understand and accept Shandong culture and clearly choose travel routes.

With Qufu as the center, depending on Confuciusassociated with tourist attractions, cultural parks, festivals, etc., it is of great advantage to create a tourism brand of "red culture + Confucian and Mencius culture", and explore the common ground between red culture and traditional culture. The advantage of the geographical position, the advantage of the geographical position is not as good as the harmony of the people" that reflects the Chinese national spirit of continuous self-improvement, that is, the integration as well as the development of the red culture, so that the excellent traditional Chinese culture can be realized. With Zibo as the center, people will deeply explore the cultural resources of Shandong, develop traditional craft products such as ceramics and glass, and create a unique "Red Culture + Shandong Culture" tourism brand with the help of folk art and modern festivals such as the Shandong Culture International Tourism Festival, ceramic prints of red heroes, red deeds, etc. Taking cities along the Yellow River as the main body, depending on scenic spots such as the Yellow River Delta National Nature Reserve Wetlands, the Yellow River Eco-tourism Area, Jinan Yellow River Forest Park, as well as traditional arts such as Shandong Opera, Bangzi, and paper-cutting, it is of great advantage to create a collection of "red culture + ecotourism + leisure", and create the Yellow River cultural tourism brand. With Linyi as the core, deeply explore the connotation of red culture, develop red cultural performance products, attach emphasis on the inheritance and protection of Yimeng film and television base and Yimeng folk songs, integrate existing red tourism routes, build red cultural tourism brands, and focus on exploring the three cities in southern Shandong The red cultural resources of the province serve as the classic guide of the province.

Table 3. Tourism resources list of three cities in southern Shandong

\begin{tabular}{|l|l|}
\hline City & $\begin{array}{l}\text { Characteristics of tourism } \\
\text { resources }\end{array}$ \\
\hline Zaozhuang & $\begin{array}{l}\text { Red culture (Former Site of } \\
\text { Tai'erzhuang War, Railway } \\
\text { Guerrilla Memorial Park), } \\
\text { celebrity culture (Mozi's } \\
\text { hometown), Beixin culture, } \\
\text { ancient canal, etc. }\end{array}$ \\
\hline Heze & Red culture (the former \\
\hline
\end{tabular}




\begin{tabular}{|c|c|}
\hline & $\begin{array}{l}\text { anti-Japanese joint } \\
\text { defense site of Hongsan } \\
\text { Village of Cao County, the } \\
\text { place where the army led } \\
\text { by Liu Bocheng and Deng } \\
\text { Xiaoping forcefully crossed } \\
\text { the Yellow River, etc.), } \\
\text { peony culture, hometown } \\
\text { of martial arts, calligraphy } \\
\text { and painting, the old } \\
\text { course of the Yellow River, } \\
\text { etc. }\end{array}$ \\
\hline Linyi & $\begin{array}{l}\text { Red culture (Cemetery of } \\
\text { Revolutionary Martyrs in } \\
\text { East China, Menglianggu } \\
\text { Battle Memorial Hall, } \\
\text { Yimeng Minor memorial } \\
\text { site, etc.), natural } \\
\text { resources such as the } \\
\text { underground } \\
\text { Canyon. }\end{array}$ \\
\hline
\end{tabular}

Taking Jining and Zaozhuang as the core and depending on Wenhe culture-related scenic spots and canal cultural tourism festivals and other festivals, it is of great importance to create a cultural tourism brand of "Red Culture + Canal Tour". Taking Jinan as the center, depending on the abundant spring water resources and the existing red resources in the central region, it is of great significance to create a cultural tourism brand of "Red Culture + Spring Water Tour". Taking coastal cities in the east such as Qingdao and Weihai as the core, depending on strong marine industry bases and abundant aquatic resources, as well as the red resources represented by the Navy Museum, it is of great advantage to create a tourism brand of "red culture + marine culture".

\section{REFERENCES}

[1] Wang, X .2012Study on the Development of Exhibition tourism in Weifang Area.[D].Full-text database of Outstanding Master's Degree Papers in ChinaFull-text database of Outstanding Master's Degree Papers in China.2

[2] Dou, Q.Y., Wang, G.S.2014The Paradigm and Practice-oriented Exploration of The Cultural Theory of Yang Jiaxuan.[J] Journal of Hebei Young Cadre Management College.

[3] Dou, J.2018"Internet" and cultural industry development strategy- take Weifang kite culture industry as an example.[J] Journal of Weifang College.

[4] Yin, C. Chen, Y.L.2008Cultural Intension in Kite Movement.[J] Shenzhou Folklore.

[5] Fang, D.D.2016The optimal configuration and application of tour guides in Weifang City. [D]Fulltext database of outstanding master's degree papers in China.
[6] Wang ,Z.2014Study on the Regional Development of Weifang High-tech Zone based on Industrial Cluster.[D]Full-text database of outstanding master's degree papers in China. 